\title{
HAK PRIORITAS DAN HAK EKSLUSIF DALAM PERLINDUNGAN HKI
}

\author{
Sufiarina \\ Fakultas Hukun Universitas Tama Jagakarsa Jakarta \\ Email : sufiarina_ole@yahoo.com
}

\begin{abstract}
In general, Intellectual Property Rights (HKI)—after being registered-allow their owners to be entitled to legal protection from which exclusive rights are recognized. The registered Intellectual Right provides its owners with legal protection within their jurisdiction nationwide. The exclusive right an owner holds for a certain term of time period enables him or her to make use of it and prevents others from using it. However, the Free Trade and the Internet phenomenon may distort the exclusivity of this right beyond its physical territory, where the unscrupulous might benefit or make profit from it in an unauthorized and illegal manner. Such a condition can be anticipated by the HKI regime by exercising priority rights. The topic in this research is examined through literary study, using descriptive-analytical method. The findings suggest that exercising priority rights can secure exclusive rights of an expatriate living in a particular country.
\end{abstract}

Keywords: Priority rights, exclusive rights, Intellectual Property Rights (HKI)

\begin{abstract}
Abstrak
HKI umumnya mendapatkan perlindungan melalui pendaftaran yang melahirkan hak ekslusif. Pendaftaran memberikan perlindungan dalam batas-batas teritorial suatu negara. Hak ekslusif dimiliki selama jangka waktu tertentu, yang memberikan kewenangan hanya kepada si pemegang hak untuk menggunakan haknya dan mencegah pihak lain menggunakan HKI tersebut. Namun akibat perdagangan bebas dan fasilitas internet kemungkinan hak ekslusif tersebut bisa saja digunakan oleh pihak lain di luar batas teritorial yang beriktikat tidak baik untuk mendapatkan keuntungan dengan menggunakan hak ekslusif secara tanpa hak dan melawan hukum. Kondisi ini dapat diantisipasi oleh rezim HKI melalui penggunaan hak prioritas. Pembahasan diperoleh melalui studi kepustakaan dengan menggunakan metode deskriptif analitis. Bahwa dengan pemanfaatan fasilitas hak prioritas maka hak ekslusif orang asing di suatu negara dapat diberikan perlindungan.
\end{abstract}

Kata kunci : Hak Prioritas, Hak Ekslusif HKI, 


\section{A. PENDAHULUAN}

Secara umum hak prioritas adalah hak yang diberikan kepada pendaftar Hak Kekayaan Intelektual, dimana tanggal penerimaan dianggap sama dengan tanggal penerimaan pertama di negara asal. Dianggap sama berarti bukanlah dalam pengertian yang sebenarnya namun berupa pengakuan saja. Hak prioritas ini merupakan aspek perlindungan HKI di negara lain. Hak kekayaan Intelektual tidak dapat dilepaskan dari perdagangan internasional.

Hak kekayaan intelektual sebagai benda tidak berwujud (intangible), memperoleh perlindungan hukum karena pendaftaran (kecuali untuk hak cipta dan rahasia dagang). Dengan pendaftaran diperoleh perlindungan bagi pemilik hak kekayaan intelektual berupa perolehan hak ekslusif. Tanpa upaya pendaftaran tidak ada perlindungan sehingga juga tidak diperoleh hak ekslusif.

Pendaftaran hak kekayaan intelektual memberikan konsekuensi perlindungan, namun perlindungan yang diberikan bersifat teritorial, hanya memperoleh perlindungan dalam wilayah negara dimana pendaftaran itu dilakukan. Di negara lain yang belum dilakukan pendaftaran hak kekayaan intelektual tersebut tentulah tidak akan memperoleh perlindungan hukum.

Pemberian hak kekayaan intelektual berdasarkan prinsip teritorial di satu sisi dan di sisi lain perpindahan barang dan jasa lintas negara secara bebas merupakan suatu antinomi. ${ }^{1}$ Diikuti dengan fasilitas internet yang bekerja sangat cepat, termasuk perkembangan e-comerce. ${ }^{2}$ Kondisi ini membawa konsekuensi perdagangan internasional, sehingga produk-produk yang dilindungi HKI di wilayah suatu negara dapat pula ditemukan di negara lain. Dengan demikian ada kemungkinan pihak lain yang tidak berhak mempunyai iktikat tidak baik atas hak kekayaan inteklektual orang asing tersebut dengan mempergunakan hak ekslusif si pemilik hak kekayaan intelektual karena belum terdaftar di negara tersebut. Sehingga pihak lain

\footnotetext{
${ }^{1}$ Antinomi merupakan suatu yang berpasangan namun saling bertentangan

${ }^{2}$ E-comerce adalah perdagangan secara elektronik, satu kemajuan sebagai dampak kemajuan teknologi informasi.
} 
yang tidak berhak memperoleh keuntungan dengan melanggar hak ekslusif pemilik hak kekayaan intelektual sesungguhnya yang nota bene adalah warga negara asing, hanya karena tidak atau belum melakukan pendaftaran di negara lain tersebut.

Ketidakadilan bagi si pemilik hak kekayaan intelektual berupa hak ekslusifnya tidak diakui, lagi pula akan mengakibatkan tujuan hukum tidak tercapai, berupa ketertiban, kepastian hukum dan keadilan. Keadaan ini diantisipasi dengan hak prioritas dalam perlindungan HKI di negara lain.

Dengan adanya hak prioritas ini, maka reward dan perlindungan HKI berlangsung terus, motivasi mereka yang bergelut di bidang eksplorasi intelektual yang mampu menghasilkan hak kekayaan intelektual, menjadi bertambah, sehingga kehidupan dan peradaban manusia juga terpacu untuk terus maju dan berkembang.

Persoalannya apakah hak prioritas ini berlaku di semua negara dan dan bagaimana mendapatkan hak prioritas tersebut. Sehingga mereka-mereka yang telah berjuang, bekerja keras untuk menghasilkan suatu hak kekayaan intelektual, juga mendapatkan perlindungan hak ekslusif di negara-negara lain.

Untuk mencari jawaban atas permasalahan tersebut penulis melakukan penelitian hukum normatif. Penelitian hukum yang dilakukan dengan cara meneliti bahan pustaka atau data skunder, dapat dinamakan penelitian hukum normatif atau penelitian hukum kepustakaan. ${ }^{3}$ Penelitian kepustakaan tersebut dapat dilakukan terhadap asas-asas hukum, dengan menggunakan metode deskriptif analisis. Dalam penelitian ini dikaji mengenai asas hukum. Bellefroid berpendapat bahwa asas hukum adalah norma dasar yang dijabarkan dari hukum positif dan yang oleh ilmu hukum tidak dianggap berasal dari aturan-aturan yang lebih umum. Asas hukum umum merupakan pengendapan hukum positif dalam suatu masyarakat, ${ }^{4}$

\footnotetext{
${ }^{3}$ Soerjono Soekanto, Penelitian Hukum Normatif, Suatu Tinjauan Singkat, PT. RajaGrafindo Persada, Jakarta, 2009, Hlm 14

${ }^{4}$ Sudikno Mertokusumo, Penemuan Hukum Sebuah Pengantar, Penerbit Liberty, Yogyakarta, 2001, Hlm 5 .
} 
bahwa pemilik hak kekayaan intelektual yang mendaftarkan hak kekayaan intelektualnya mendapatkan perlindungan hukum berupa hak ekslusif.

\section{B. PEMBAHASAN}

\section{Pengertian HKI}

Hak kekayaan Intelektual (selanjutnya disingkat HKI) merupakan terjemahan resmi dari Intellectual Property Rights. HKI lahir setelah Revolusi Industri, dimulai dari Paris Convention for the Protection of Industrial Property dan Berne Conventonfor the Protection of Artistic and Literaty works di abad ke 19. ${ }^{5}$ Hak kekayaan intelektual bernuansa ekonomi dan tertuang dalam beberapa perjanjian internasional, sehingga konsep HKI menjadi universal dengan mengundang sebanyak mungkin negara menjadi peserta.

Berdasarkan substansinya menurut Tomy Suryo Utomo ${ }^{6} \mathrm{HKI}$ berhubungan erat dengan benda (tidak berwujud) serta melindungi karya intelektual yang lahir dari cipta, rasa dan karsa manusia. WIPO (World Intellectual Property Organization), sebuah lembaga internasional di bawah PBB yang menangani masalah HKI, mendefinisikan HKI sebagai; " kreasi yang dihasilkan dari pikiran manusia yang meliputi; invensi, karya sastra dan seni, simbol, nama, citra dan desain yang digunakan di dalam perdagangan”.

Ditjen HKI bekerja sama dengan ECAP mendefinisikan HKI sebagai; "hak yang timbul bagi hasil olah pikir otak yang menghasilkan suatu produk atau proses yang berguna untuk manusia". ${ }^{7}$ Secara sederhana HKI adalah suatu hak lahir sebagai hasil pemikiran kreasi intelelektual yang menghasilkan produk yang bermanfaat bagi manusia. HKI juga bisa diartikan sebagai hak bagi seseorang karena ia telah

\footnotetext{
${ }^{5}$ Achmad Zen Umar Purba, Hak Kekayaan Intelectual Pasca TRIPs, Alumni, Bandung, 2005, hl, vii

${ }^{6}$ Tomy Suryo Utomo, Hak Kekayaan Intelektual (HKI) di Era Global, Graha Ilmu, Yogyakarta, 2010, hlm 1.

${ }^{7}$ Ditjen HKI (Bekerja sama dengan EC-ASEAN IPRs Co-operation Programme (ECAP II), Buku Panduan Hak Kekayaan Intelektual Dilengkapi dengan Peraturan Perundang-Undangan Di Bidang Hak Kekayaan Intelektual, Jakarta, ditjen HKI-ECAP II, 2006, hlm 7
} 
membuat sesuatu yang berguna bagi orang lain. Objek yang diatur dalam HKI adalah karya-karya yang lahir dari kemampuan intelektual (daya pikir) manusia.

Adapun dari definisi di atas, HKI selalu dikaitkan dengan tiga elemen berikut ini: ${ }^{8}$

a. Adanya sebuah hak ekslusif yang diberikan oleh hukum;

b. Hak tersebut berkaitan dengan usaha manusia yang didasarkan pada kemampuan intelektual;

c. Kemampuan intelektual tersebut memiliki nilai ekonomi.

Karya-karya intelektual tersebut dilahirkan dengan pengorbanan menjadikan karya yang dihadirkan menjadi bernilai, apalagi dengan manfaat ekonomi yang dapat dinikmati, maka nilai ekonomi yang melekat menumbuhkan konsep kekayaan (property) terhadap karyakarya intelektual itu bagi dunia usaha, atau karya-karya itu dikatakan sebagai suatu asset.

Hak ekslusif yang diberikan oleh hukum merupakan reward yang sesuai bagi para investor dan pencipta HKI. Melalui rewards tersebut orang-orang yang kreatif didorong untuk terus mengasah kemampuan intelektualnya agar dapat dipergunakan untuk membantu peningkatan kehidupan manusia. Tujuan utama sistem hukum HKI adalah menjamin agar proses kreatif tersebut terus berlangsung dengan menyediakan perlindungan hukum yang memadai dan menyediakan sanksi terhadap pihak yang menggunakan proses kreatif tersebut tanpa izin.

HKI pada intinya terdiri dari beberapa jenis, yang secara konvensional dipilah dalam 2 kelompok, yaitu:

a) Hak Cipta (copyright) dan hak-hak terkait

b) Hak atas Kekayaan Industri (Industrial Property) yang berisikan

1) Paten/ Patent

2) Merek / Trademark

\footnotetext{
${ }^{8}$ Lihat Tomy Suryo, Op-cit hlm 2
} 
3) Desain Industri / Industrial Design

4) Desain Tata Letak Sirkuit Terpadu

5) Rahasia Dagang / Trade Secret

6) Varietas Tanaman

2. Beberapa Prinsip Umum HKI yang terkait dengan Perlindungan Bagian ini akan mendiskusikan tentang prinsip-prinsip umum yang berlaku dalam Hak Kekayaan Intelektual seperti:

a. Prinsip HKI sebagai hak ekslusif

Maksudnya hak yang diberikan oleh HKI bersifat khusus dan hanya dimiliki oleh orang yang terkait langsung dengan kekayaan intelektual yang dihasilkan. Melalui hak tersebut pemegang hak dapat mencegah orang lain untuk membuat, menggunakan atau berbuat sesuatu tanpa izin.

b. Prinsip melindungi karya intelektual berdasarkan pendaftaran

Secara umum pendaftaran merupakan syarat bagi kekayaan intelektual yang dihasilkan oleh seseorang untuk mendapatkan perlindungan. Beberapa cabang HKI yang mewajibkan seseorang untuk melakukan pendaftaran adalah Merek, Paten, Desain Industry, Desain Tata Letak Sirkuit Terpadu dan Perlindungan Varietas Tanaman. Prinsip ini mendasari semua regulasi HKI di seluruh dunia dan membawa konsekuensi bahwa pemilik kekayaan intelektual yang tidak melakukan pendaftaran tidak dapat menuntut seseorang yang dianggap telah menggunakan kekayaannya secara melawan hukum. Beberapa pengecualian diberikan oleh hukum nasional negara tertentu yang dapat melakukan tuntutan terhadap pelanggaran hukum terkait hak kekayaan intelektual meskipun kekayaan intelektualnya belum terdaftar ${ }^{9}$.

c. Prinsip perlindungan yang dibatasi oleh batasan teritorial

\footnotetext{
${ }^{9}$ Tomy Suryo Utomo, Op-cit, hlm 13
} 
Sistem HKI mengatur bahwa pendaftaran yang melahirkan perlindungan Hukum bersifat territorial. Artinya perlindungan Hukum hanya diberikan ditempat pendaftaran tersebut dilakukan. Sistem ini selaras dengan kedaulatan negara di dalam hukum publik dimana keputusan yang dihasilkan oleh perangkat administrasi negara tidak dapat dipaksakan berlaku di negara lainnya. Dalam rezim HKI setiap negara bebas untuk menerima sebuah pendaftaran kekayaan intelektual. Keputusan yang diambil oleh sebuah negara tidak berpengaruh terhadap putusan yang akan diambil oleh negara lain.

d. Prinsip adanya pemisahan antara benda secara fisik dengan HKI yang terdapat dalam benda tersebut

Sistem ini bersifat sangat unik dan merupakan ciri khas HKI karena dalam cabang hukum lain yang bersifat berwujud (tangible), penguasaan secara fisik dari sebuah benda sekaligus membuktikan kepemilikan yang sah atas benda tersebut. Di dalam sistem HKI seseorang yang menguasai benda secara fisik tidaklah otomatis memiliki hak ekslusif dari benda fisik itu. Sebagai contoh, jika seseorang membeli sebuah buku maka orang itu hanya berhak atas buku tersebut (benda secara fisik) untuk penggunaan secara pribadi, misalnya dibaca, diberikan sebagai hadiah kepada orang lain).

e. Prinsip perlindungan HKI bersifat terbatas Meskipun ada cabang HKI (merek) yang dapat diperpanjang jangka waktu perlindungannya, secara umum jangka waktu perlindungan HKI tidaklah bersifat selamanya (hanya terbatas). Tujuan pembatasan perlindungan ini adalah untuk memberikan kesempatan kepada masyarakat mengakses hak kekayaan intelektual tersebut secara optimal melalui usaha-usaha pengembangan lebih lanjut dan sekaligus mencegah monopoli atas kekayaan intelektual tersebut.

f. Prinsip HKI yang berakhir jangka waktu perlindungannya berubah menjadi public domain 
HKI yang telah berakhir jangka waktu perlindungannya akan menjadi milik umum (public domain). Semua orang berhak untuk mengakses HKI yang telah berakhir waktu perlindungannya. Pasca berakhirnya perlindungan hukum pemegang HKI tidak boleh menghalangi atau melakukan tindakan seolah-olah masih memiliki hak ekslusif. Sebagai contoh perjanjian lisensi dengan kewajiban membayar royalty bagi pihak licensee tidak boleh dilakukan jika jangka waktu perlindungan HKI yang menjadi dasar bagi terjadinya perjanjian tersebut telah berakhir.

3. Hak Prioritas

Hak prioritas bersumberkan kepada Paris Convention yang asasasasnya telah digabungkan di dalam TRIPs. Ketentuan-ketentuan Paris Convention yang terpenting adalah sebagai berikut: ${ }^{10}$

1. Penanganan nasional atau similasi nasional yang mengatur bahwa sejauh berkaitan dengan milik industrial, setiap anggota harus memberikan perlindungan yang sama kepada warga negara dari negara anggota lain sebagaimana ia berikan kepada warga negaranya sendiri. Penangangan seperti ini dikenal dengan principle of national treatment. Inti national treatment adalah pada pemberlakuan yang sama dalam kaitan dengan perlindungan kekayaan intelektual antara yang diberikan kepada warga negara sendiri dan warga negara lain. ${ }^{11}$

2. Penggunaan hak prioritas atas dasar permintaan pendaftar pertama di negara anggota, pemohon dapat di dalam periode tertentu 6 atau 12 bulan meminta perlindungan seolah-olah didaftarkan pada hari yang sama pada permintaan pertama.

Khusus bagi negara bukan anggota diberlakukan asas principle of independence, artinya pemberian HKI di suatu negara tidak

\footnotetext{
${ }^{10}$ Endang Purwaningsih, Hukum Bisnis, Ghalia Indonesia, Jakarta, hlm, 134

${ }^{11}$ Achmad Zen Umar Purba, Hak Kekayaan Intelektual Pasca Trips, Alumni, Bandung, 2005. Hlm 24
} 
mewajibkan negara lain memberikan HKI. Inti dari pengertian prioritas adalah menggunakan tanggal penerimaan permintaan pendaftaran atau filling date. ${ }^{12}$ Jadi hak prioritas berkaitan dengan jangka waktu pendaftaran yang memberikan anggapan mendaftar lebih awal dari fakta yang sesungguhnya.

Berarti disini hak prioritas adanya berdasarkan permohonan, dan tidak terjadi dengan sendirinya secara otomatis. Maksud dari pengertian prioritas adalah dengan menggunakan dan menempatkan tanggal penerimaan dianggap sama dengan tanggal penerimaan di negara asal. Dianggap sama tentunya dalam arti seolah-olah, bukan yang sesungguhnya. Berarti ini adalah suatu fiksi suatu anggapan. Fiksi ialah, bahwa kita menerima sesuatu yang tidakbenar sebagai suatu hal yang benar. Dengan perkataan kita menerima apa yang sebenarnya tidak ada, sebagai ada atau yang sebenarnya ada sebagai tidak ada. ${ }^{13}$ Bahwa tiap-tiap konstruksi atau pembentukan pengertian terletak sesuatu fiksi, karena orang hanya melihat sifat-sifat dari sesuatu yang konkrit yang bersamaan dengan sifat-sifat yang lain, jadi sifat-sifatnya yang umum dan mengabrasinya dari sifat-sifat yang khusus. Van Apeldoorn mengatakan fiksi itu biasa dipakai jika orang dengan sadar menerima sesuatu sebagai benar, apa yang tidak benar. Fiksi-fiksi tersebut mempunyai sifat yang tak berbahaya, bahkan lebih dari pada itu, orang dapat mengatakan, bahwa fiksi perundangundangan itu bukan fiksi sebenarnya, melainkan dirumuskan belaka sebagai fiksi. ${ }^{14}$

Fiksi perundang-undangan tak pernah menyatakan persamaan fakta melainkan memberikan penilaian yuridis yang sama terhadap hubungan hubungan yang berbeda satu sama lain. Mengindahkan hal itu adalah sangat besar faedahnya untuk penafsirkan peraturan perundang-undangan yang dirumuskan sebagai fiksi, karena di

\footnotetext{
${ }^{12}$ Endang Purwaningsih, op-cit, hlm 135

${ }^{13}$ Van Apeldoorn, Pengantar Ilmu Hukum, Pradnya Paramita, Jakarta, 1996, hlm 407

${ }^{14}$ Ibid.
} 
dalamnya ada terkandung, bahwa tiada dapatlah orang dengan begitu saja menghubungkan akibat hukum yang timbul dari hubunganhubungan khayal kepada hubungan-hubungan lain yang diberi nilai sama dengan hubungan-hubungan khayal itu.

4. Sistem Pendaftaran dan Perlindungan HKI berupa hak esklusif

Perlindungan hak cipta lahir pada saat ide telah diwujudkan ke dalam bentuk nyata (fixation). Oleh karena itu hak cipta ini tidak memerlukan pendaftaran guna memperoleh perlindungan, perlindungan itu ada secara otomatis ketika ide telah diwujudkan, walaupun beberapa negara mencantumkan juga tentang pendaftaran hak cipta, namun tujuan pendaftaran tersebut adalah sebagai alat bukti di pengadilan jika terjadi sengketa terhadap hak cipta yang dimiliki seseorang.

Bagi rahasia dagang unsur pendaftaran bukanlah syarat untuk perlindungan, mengingat sifat secret dari rahasia dagang terkait dengan informasi yang tidak diketahui oleh umum. Meskipun demikian perjanjian lisensi terkait rahasia dagang dapat didaftarkan. Hanya saja yang didaftarkan adalah syarat dan isi perjanjiannya, bukan rahasia itu sendiri.

Dalam sistem pendaftaran HKI secara umum dikenal dua cara pendaftaran HKI yaitu:

a. Fisrt to file system

Sistem pendaftaran ini didasarkan pada pendaftar pertama. Artinya jika ada dua orang yang mendaftarkan kekayaan intelektual pada hari yang sama dengan objek yang sama, maka pihak yang mendaftarkan lebih dahululah yang diprioritaskan untuk diproses, disebut juga dengan pendaftaran konstitutif.

b. Fisrt to use system

Sistem ini didasarkan pada pengguna pertama, artinya pemilik kekayaan intelektual yang akan didaftar adalah orang yang pertama menggunakan kekayaan intelektual tersebut, sistem ini dinamakan juga dengan sistem deklaratif. 
Melalui pendaftaran hak kekayaan intelektual ini, maka negara memberikan perlindungan kepada orang yang memenuhi persyaratan untuk mendaftar, dan akan memberikan hak ekslusif kepada yang telah berhasil melakukan pendaftaran. Perlindungan yang dimaksud berupa penerimaan hak ekslusif yang bersifat monopoli untuk waktu tertentu dan hanya dimiliki oleh orang yang terkait langsung dengan kekayaan intelektual yang didaftarkan tersebut. Melalui hak ekslusif pemilik hak kekayaan intelektual dapat mencegah orang lain untuk membuat, menggunakan atau berbuat sesuatu terhadap hak kekayaan intelektual tersebut tanpa izin.

Hak esklusif ${ }^{15}$ mempunyai dua muatan yaitu hak ekonomi ${ }^{16}$ untuk memperoleh keuntungan finansial dari perolehan pengakuan hak kekayaan intelektual berupa pengalihan dan pemberian izin penggunaan HKInya dengan memperoleh royalti dan hak moral ${ }^{17}$ yang selalu melekat atas diri si pemilik HKI yang bersifat tetap dan tidak dapat dialihkan.

Hak ekslusif yang diberikan tersebut sesungguhnya berupa hak monopoli untuk jangka waktu yang terbatas, sebagai imbangan yang diberikan negara kepadanya atas banyak pengorbanan yang telah dilakukan untuk perolehan HKI. Hak monopoli tidak untuk selamanya namun hanya dalam jangka waktu tertentu (terbatas). Dalam waktu yang telah ditentukan tersebut ${ }^{18}$ hanya yang memiliki hak yang dapat berbuat bebas terhadap HKInya, sedangkan bagi pihak lain harus mengakui HKInya tersebut melalui permintaan izin terlebih dahulu untuk dapat berbuat atas HKI pihak lain dengan membayar sejumlah

\footnotetext{
${ }^{15}$ Hak ekslusif adalah hak yang semata-mata diperuntukkan bagi pemegangnya, sehingga pemegang hak dapat mencegah orang lain untuk meniru atau menggunakan HKI tanpa izin. Lihat Otto Hasibuan, Hak Cipta di Indonesia, Alumni Bandung, 2008, hlm 63. Lihat juga Suyud Margono, Aspek Hukum Komersialisasi Aset Intelektual, Nuansa Aulia, Bandung, 2010. hlm 128

${ }^{16}$ Hak ekonomi adalah hak untuk mendapatkan manfaat ekonomi atas HKI, lihat Iswi Hariyani, Prosedur Mengurus HKI Yang Benar, Pustaka Yustisia, Yogyakarta, 2010, hlm 61

${ }^{17}$ Hak moral adalah hak yang melekap pada pihak yang menghasilkan HKI yang tidak dapat dihilangkan atau dihapus tanpa alasan apapun. Ada kemanunggalan yang integral antara HKI dan pihak yang berhasil melahirkan HKI. Lebih lanjut lihat Otto Hasibuan, Hak Cipta di Indonesia, Alumni Bandung, 2008, hlm 69

${ }^{18}$ Lihat waktu perlindungan untuk masing-masing jenis hak kekayaan intelektual tersebut.
} 
royalti. Apabila menggunakan Hak ekslusif tersebut tanpa izin dikategorikan sebagai perbuatan yang melanggar hak kekayaan intelektual pihak lain baik dari aspek perdata maupun dari aspek pidana secara sekaligus.

Apabila masa perlindungan telah habis, maka hak ekslusif yang bersifat ekonomis menjadi lenyap, maka si pemilik HKI tidak lagi dilindungi dalam penggunaan HKI nya berarti hak ekslusifnya hilang dan pihak lain dapat mempergunakan HKI tersebut secara bebas, tanpa izin dan tanpa royalty. Lenyapnya hak ekslusif penguasaan HKI yang telah habis masa perlindungannya beralih mempunyai fungsi sosial.

5. Hak Prioritas dan Hak Ekslusif dalam Pendaftaran HKI

Kajian mengenai HKI khususnya hak kekayaan industri tidaklah dapat dilepaskan dari historis eksistensi Paris Convention yang asasasasnya telah digabungkan di dalam TRIPs. Berdasarkan ketentuanketentuan Paris Convention bahwa; ${ }^{19}$ Penanganan nasional atau similasi nasional yang mengatur bahwa sejauh berkaitan dengan milik industrial, setiap anggota harus memberikan perlindungan yang sama kepada warga negara dari negara anggota lain sebagaimana ia berikan kepada warga negaranya sendiri. Penangangan seperti ini dikenal dengan principle of national treatment. Inti national treatment adalah pada pemberlakuan yang sama dalam kaitan dengan perlindungan kekayaan intelektual antara yang diberikan kepada warga negara sendiri dan warga negara lain. ${ }^{20}$

Penggunaan hak prioritas atas dasar permintaan pendaftar pertama di negara anggota, pemohon dapat di dalam periode tertentu 6 atau 12 bulan meminta perlindungan seolah-olah didaftarkan pada hari yang sama pada permintaan pertama.

Khusus bagi negara bukan anggota diberlakukan asas principle of independence, artinya pemberian HKI di suatu negara tidak mewajibkan

\footnotetext{
${ }^{19}$ Endang Purwaningsih, Hukum Bisnis, Ghalia Indonesia, Jakarta, hlm, 134

${ }^{20}$ Achmad Zen Umar Purba, Hak Kekayaan Intelektual Pasca Trips, Alumni, Bandung, 2005. Hlm 24
} 
negara lain memberikan HKI. Inti dari pengertian prioritas adalah menggunakan tanggal penerimaan permintaan pendaftaran atau filling date. ${ }^{21}$ Jadi hak prioritas berkaitan dengan jangka waktu pendaftaran yang memberikan anggapan mendaftar lebih awal dari fakta yang sesungguhnya.

Dengan pelaksanaan pendaftaran HKI di negara lain, maka secara yuridis HKI yang telah didaftarkan tersebut memperoleh perlindungan dengan mendapatkan hak ekslusifnya di negara tersebut selama jangka waktu perlindungan. Bagi negara-negara sesama anggota Paris Convention, dalam pendaftaran HKI bagi warga asing dapat menggunakan permohonan dengan hak prioritas, dalam arti HKI didaftarkan dengan maksud memperoleh perlindungan, serta dengan hak prioritas maka perlindungan berupa hak ekslusif itu dianggap sudah ada sebelum pendaftaran dilakukan. Sebelum pendaftaran dalam arti perlindungan telah dianggap ada pada sejak penerimaan pendaftaran di negara asal. Bagi pihak lain yang secara tanpa hak menggunakan HKI yang didaftarkan tersebut, baik sebelum ataupun sesudah pendaftaran HKI dapat dikenakan tuntutan ganti rugi atau dilaporkan melakukan tindak pidana dan penyelesaian menurut hukum.

Prinsip pokok dalam Paris Convention adalah tidak diperkenankan negara peserta konvensi melakukan diskriminasi terhadap negara sesama peserta anggota Paris Convention. Jadi tidak ada alasan untuk lebih memprioritaskan warga negaranya dibandingkan dengan warga negara lain. Dalam regulasi HKI di Indonesia pengaturan hak prioritas dapat ditemukan dalam beberapa ketentuan berikut: Pasal 1 angka 12 UU No. 31 Tahun 2000 tentang Desain Industri, Pasal 1 angka 12 UU No.14 Tahun 2001 tentang Paten, Pasal 1 angka 14 UU No. 15 Tahun 2001 tentang Merek.

6. Asas resiprositas dalam penggunaan hak prioritas

\footnotetext{
${ }^{21}$ Endang Purwaningsih, op-cit, hlm 135
} 
Pendaftaran HKI secara hak prioritas sesuai dengan Paris Convention hanya diperuntukkan bagi negara-negara sesama anggota Paris Convention secara repsirositas. Berdasarkan asas resiprositas, dengan menegakkan asas pemberian perlakuan yang sama atas hak asas reprositas, artinya kesediaan, kerelaan, memberi perlindungan yang sama terhadap pelayanan permintaan pendaftaran HKI dengan hak prioritas terhadap asing orang harus berdasarkan asas timbal balik.

Perlakuan pemberian perlindungan hukum yang sama. Rezim HKI memberi perlindungan yang sama terhadap pemilik HKI asing, sebagaimana perlakuan perlindungan yang diberikan kepada pemilik HKI warga negara sendiri. Asas resiprositas dengan sendirinya bercorak multilateral terhadap semua negara anggota Paris Convention, artinya jika pemohon bukan dari negara peserta Paris Convention, kantor HKI mereka harus menolak pendaftaran dengan hak prioritas dengan alasan tidak ditegakkan asas Reprositas.

Permohonan dengan menggunakan hak prioritas harus diajukan dalam waktu tertentu ( 6 atau 12 bulan) terhitung sejak tanggal perincian permohonan yang pertama kali diterima di negara lain yang merupakan anggota Paris Convention atau anggota Persetujuan Pembentukan Organisasi Perdagangan Dunia. Permohonan dengan hak prioritas tersebut wajib dilengkapi dengan dokumen prioritas yang disahkan oleh kantor penyelenggara pendaftaran HKI dimaksud disertai terjemahannya.

Apabila syarat-syarat sebagaimana dimaksud di atas tidak dipenuhi permohonan tersebut dianggap diajukan tanpa menggunakan hak prioritas. Selain persyaratan salinan surat permohonan sebagaimana dimaksud dalam Pasal 16 ayat (2) Direktorat Jenderal (Kantor HKI) dapat meminta agar permohonan dengan menggunakan hak prioritas dilengkapi pula dengan:

1) Salinan lengkap HKI yang telah diberikan sehubungan dengan pendaftaran yang pertama kali diajukan di negara asal; dan 
2) Salinan dari dokumen lain yang diperlukan untuk mempermudah penilaian bahwa HKI yang akan didaftar tersebut baru.

Tanggal penerimaan (filling date) dinyatakan sebagai tanggal diterimanya permohonan dari pemohon yang telah;

1) Mengisi formulir permohonan

2) Melampirkan contoh fisik atau gambar atau foto dan uraian dari HKI yang dimohonkan pendaftarannya dan;

3) Membayar biaya permohonan

Pendaftaran HKI oleh warga negara asing tidaklah selalu otomatis menggunakan hak prioritas namun dengan memenuhi persyaratan tertentu. Hak prioritas diberikan jikalau didahului dengan permohonan menggunakan hak prioritas. Apabila persyaratan telah dipenuhi maka warga negara asing yang telah mendaftarkan HKInya di negara asal, dapat diberikan prioritas bahwa tanggal penerimaan di negara tujuan (asing) dianggap sama dengan tanggal penerimaan di negara asal sepanjang negara-negara tersebut sama-sama menjadi anggota Paris Convention.

Pendaftaran HKI di negara asing dengan menggunakan fasilitas hak prioritas membawa konsekuensi hak esklusif dari pemilik HKI menjadi berlaku surut pula sejak tanggal mendaftar di negara asal menjadi berlaku sama di negara tujuan. Sehingga bagi pihak-pihak lain yang beriktikat tidak baik menggunakan HKI pihak lain tanpa hak dan melawan hukum, dapat dilawan oleh pemilik HKI dengan menggunakan hak esklusif yang dianggap telah ada sebelum pendaftaran HKI dilaksanakan, sepanjang pendaftaran dengan menggunakan hak prioritas. Dengan demikian hak pemilik HKI meskipun mendaftarkan HKInya belakangan dibandingkan dengan di negara asalnya, sepanjang pendaftaran dilakukan dengan hak prioritas tetap mendapatkan perlindungan hak esklusifnya di negara lain yang dianggap hak ekslusifnya telah ada sejak HKInya didaftarkan di 
negara asal. Keadaan ini memberikan jangka waktu perlindungan hak ekslusif yang sama, tidak menjadi berkurang meskipun pendaftaran dilakukan kemudian. Apabila tidak dilakukan dengan hak prioritas maka jangka waktu hak ekslusifnya berkurang, pendaftaran dan perlindungan HKI menjadi tidak lagi relevan. Sebab HKI hanya diberikan perlindungan dalam jangka waktu tertentu untuk memaksimalkan hak ekslusifnya (kecuali merek yang memang selalu dapat dilakukan perpanjangan).

Pentingnya hak prioritas berupa hak bagi warga negara asing, yang berasal dari negara yang sama-sama tergabung dalam Paris Convensi atau persetujuan pembentukan Organisasi Perdagangan dunia, untuk memperoleh pengakuan bahwa tanggal penerimaan yang diajukan sama dengan tanggal penerimaan yang diajukan di negara asal.

Dalam hal ini hak prioritas bersifat repsirokal bagi negara-negara yang sama-sama tergabung dalam Paris Convention atau persetujuan pembentukan Organisasi Perdagangan Dunia untuk menganggap (fiksi) pendaftaran yang dilakukan belakangan dianggap sama dengan tanggal penerimaan di negara asal. Jadi semua negara yang tergabung dalam Paris Convention atau Persetujuan Pembentukan Organisasi Perdagangan Dunia terikat untuk memberikan perlindungan kepada negara lain yang warga negaranya bermaksud mendaftarkan HKI di negara tersebut sepanjang masih dalam jangka waktu perlindungan yang telah ditentukan berdasarkan Paris Convention.

Bagi negara-negara yang tidak tergabung dalam Paris Convention, maka di negara tersebut tidak berlaku hak prioritas. Bagi warga negara asing dari negara yang tidak tergabung dalam Paris Convention, maka warga dari negara yang besangkutan (tidak tergabung dalam Paris Convention) tidaklah memiliki hak prioritas dalam pendaftaran HKI. 


\section{PENUTUP}

1. Kesimpulan

Berdasarkan bahasan di atas dapat dibuat kesimpulan sebagai berikut:

a. Hak prioritas dalam perlindungan HKI hanya diperuntukkan bagi negara-negara sesama yang tergabung dalam Paris Convention atau persetujuan pembentukan organisasi perdagangan dunia, secara resiprokal.

b. Hak prioritas menghendaki tidak ada diskriminasi bagi warga negara asing dalam mendaftarkan HKInya di negara yang tergabung dalam persetujuan Paris Convention atau Persetujuan Pembentukan Organisasi Perdagangan Dunia.

c. Tidaklah setiap pendaftarakan HKI oleh WNI disertai dengan hak prioritas. Hak prioritas diberikan apabila disertai dengan permohonan untuk diberikan hak prioritas, dalam jangka waktu tertentu dan dengan memenuhi persyaratan tertentu.

d. Pendaftaran HkI dengan hak prioritas memberikan anggapan hak ekslusif dianggap telah dipunyai sebelum pendaftaran HKI yaitu pada saat bersamaan dengan tanggal penerimaan pertama di negara asal.

2. Saran

Saran yang dapat penulis rekomendasikan, dalam hal pendaftaran HKI di negara lain khususnya yang sama-sama tergabung dalam Paris Convention, agar pendaftar di negara lain untuk memohonkan pendaftaran HKI secara prioritas sehingga tanggal penerimaan di negara lain akan dianggap sama dengan tanggal penerimaan di negara asal. Dengan demikian hak ekslusif yang terbit dari pendaftaran HKI dapat diperoleh secara maksimal oleh pemilik HKI tentu saja dengan memperhatikan jangka waktu dan persyaratan administrasi lainnya. 


\section{DAFTAR PUSTAKA}

Achmad Zen Umar Purba, Hak Kekayaan Intelectual Pasca TRIPs, Alumni, Bandung.

Ditjen HKI (Bekerja sama dengan EC-ASEAN IPRs Co-operation Programme (ECAP II), Buku Panduan Hak Kekayaan Intelektual Dilengkapi dengan Peraturan Perundang-Undangan Di Bidang Hak Kekayaan Intelektual, Jakarta, ditjen HKI-ECAP II, 2006.

Endang Purwaningsih, Hukum Bisnis, Ghalia Indonesia, Jakarta, 2010.

Iswi Hariyani, Prosedur Mengurus HKI Yang Benar, Pustaka Yustisia, Yogyakarta, 2010.

L.J. van Apeldoorn, Pengantar Ilmu Hukum, Pradnya Paramita, Jakarta, 1996.

Otto Hasibuan, Hak Cipta di Indonesia, Alumni Bandung, 2008.

Soerjono Soekanto, Penelitian Hukum Normatif, Suatu Tinjauan Singkat, PT. RajaGrafindo Persada, Jakarta, 2009.

Suyud Margono, Aspek Hukum Komersialisasi Aset Intelektual, Nuansa Aulia, Bandung, 2010.

Sudikno Mertokusumo, Penemuan Hukum Sebuah Pengantar, Penerbit Liberty, Yogyakarta, 2001.

Tomy Suryo Utomo, Hak Kekayaan Intelektual (HKI) di Era Global, Graha Ilmu, Yogyakarta, 2010.

Undang-Undang RI. No 15 Tahun 2001 tentang Merek.

Undang-Undang RI. No. 14 Tahun 2001 tentang Paten.

Undang-Undang RI No. 31 Tahun 2000 tentang Desain Industri. 